Olfa Kanoun, Faouzi Derbel, and Nabil Derbel (Eds.)

Sensors, Circuits and Instrumentation Systems 


\section{Advances in Systems, Signals and Devices}

Edited by

Olfa Kanoun, University of Chemnitz, Germany

\section{Volume 10}




\section{Sensors, Circuits and Instrumentation Systems}

Edited by Olfa Kanoun, Faouzi Derbel, and Nabil Derbel 


\section{Editors of this Volume}

Prof. Dr.-Ing. Olfa Kanoun

Technische Universität Chemnitz

Chair of Measurement and Sensor Technology

Reichenhainer Strasse 70

09126 Chemnitz

Germany

olfa.kanoun@etit.tu-chemnitz.de

Prof. Dr.-Ing. Faouzi Derbel

Leipzig University of Applied Sciences

Chair of Smart Diagnostic and Online Monitoring

Wächterstrasse 13

04107 Leipzig

Germany

faouzi.derbel@htwk-leipzig.de
Prof. Dr.-Eng. Nabil Derbel

University of Sfax

Sfax National Engineering School

Control \& Energy Management Laboratory 1173 BP, 3038 Sfax

Tunisia

n.derbel@enis.rnu.tn

ISBN 978-3-11-059025-8

e-ISBN (PDF) 978-3-11-059256-6

e-ISBN (EPUB) 978-3-11-059128-6

ISSN 2365-7493

Library of Congress Control Number: 2019931924

Bibliographic information published by the Deutsche Nationalbibliothek The Deutsche Nationalbibliothek lists this publication in the Deutsche Nationalbibliografie; detailed bibliographic data are available on the Internet at http://dnb.dnb.de.

(C) 2019 Walter de Gruyter GmbH, Berlin/Boston

Typesetting: VTeX UAB, Lithuania

Printing and binding: $\mathrm{CPI}$ books $\mathrm{GmbH}$, Leck

www.degruyter.com 